\title{
Are there benefits of low doses of ACE inhibitors, MRAs, diuretics and statins in the treatment of heart failure?
}

\author{
V. A. Lysenko (iD* \\ Zaporizhzhia State Medical University, Ukraine
}

Treatment of chronic heart failure (CHF) is very controversial. The issue of optimal doses of beta-blockers, ACE inhibitors, aldosterone receptor antagonists, statins in patients with CHF has not been conclusively addressed. Achieving the maximum tolerated doses of drugs, though related to reduced mortality, but is accompanied by an increase in adverse drug reactions.

The aim. To present and discuss our own clinical and scientific data concerning the role of beta-blockers and inhibitors of the reninangiotensin aldosterone system, diuretics, statins in the treatment of CHF patients and optimization of dosage schemes.

Material and methods. The study included 88 patients with CHF of ischemic origin, with sinus rhythm, stage II AB, NYHA FC II-IV, 58 - with reduced LV EF (HFrEF) and 30 - with preserved LV EF (HFpEF). The mean age of patients was $69.18 \pm 9.97$ years, men $52 \%(n=46)$. The median follow-up of the CHF patients was 396 days, the maximum number of follow-up days was 1302 . During the observation period, 14 endpoints were registered, which accounted for $15.91 \%$ of events: 7 deaths $(8.0 \%), 2$ strokes $(2.3 \%)$, 2 cases of acute coronary syndrome $(2.3 \%), 3$ progressive heart failure cases $(3.4 \%)$. Kaplan-Mayer curves were drawn to assess survival rate, and the significance of difference between groups was calculated by the criteria of Gehan-Wilcoxon, Cox-Mantel and logrank test. Risk factors were determined, and prognostic uni- and multi-variant Cox proportional hazards regression models were used. The cut-off values of quantitative risk factors were obtained by ROC analysis.

Results. The increase in the relative risk of adverse cardiovascular events in the CHF patients regardless of LV EF was associated with a daily carvedilol dose of more than $25 \mathrm{mg}(\mathrm{HR}=1.05 ; 95 \% \mathrm{Cl} 1.009-1.093 ; \mathrm{P}=0.0171)$; eplerenone - more than $12.5 \mathrm{mg}$ $(\mathrm{HR}=1.073 ; 95 \% \mathrm{Cl} 1.005-1.144 ; \mathrm{P}=0.034)$, torasemide - more than $5 \mathrm{mg}(\mathrm{HR}=1.13 ; 95 \% \mathrm{Cl} 1.021-1.255 ; \mathrm{P}=0.019)$; rosuvastatin - more than $10 \mathrm{mg}(\mathrm{HR}=1.107 ; 95 \% \mathrm{Cl} 1.007-1.203 ; \mathrm{P}=0.035)$, and the trend in using atorvastatin at a dose of less than $10 \mathrm{mg}(\mathrm{HR}=1.05 ; 95 \% \mathrm{Cl} 0.951-1.165 ; \mathrm{P}=0.327)$. The use of ramipril in a daily dose of less than $2.5 \mathrm{mg}$ was accompanied by a trend towards the $22 \%$ reduced relative risk of adverse cardiovascular events $(H R=0.78 ; 95 \% \mathrm{Cl} 0.384-1.580 ; \mathrm{P}=0.491)$.

Conclusions. Positive treatment outcomes in the CHF patients, regardless of the phenotype, were associated with low daily doses of ramipril $(<2.5 \mathrm{mg})$, eplerenone/spironolactone $(<12.5 \mathrm{mg})$, torasemide $(<5.0 \mathrm{mg})$, rosuvastatin $(<10.0 \mathrm{mg})$, but with high doses of atorvastatin $(>10.0 \mathrm{mg})$.

Key words: chronic heart failure, ACE inhibitors, MRAs, diuretics, statins, treatment.

Current issues in pharmacy and medicine: science and practice 2021; 14 (2), 226-231

Чи існують переваги низьких доз ІАПФ, АМР, діуретиків і статинів під час лікування хронічної серцевої недостатності?

\section{В. А. Лисенко}

Лікування хронічної серцевої недостатності $(\mathrm{XCH})$ дуже суперечливе. Питання про оптимальні дози бета-адреноблокаторів, інгібіторів АПФ, антагоністів рецепторів альдостерону, статинів у пацієнтів із ХСН остаточно не вирішене. Досягнення максимально переносних доз ліків хоча й пов'язане зі зниженням смертності, але супроводжується збільшенням побічних ефектів препаратів.

Мета роботи - навести й обговорити власні клінічні та наукові дані, що стосуються ролі бета-адреноблокаторів, інгібіторів ренін-ангіотензинової альдостеронової системи, діуретиків, статинів у лікуванні хворих на ХCH, а також оптимізації режимів дозування.

Матеріали та методи. У дослідження залучили 88 хворих на ХCH ішемічного ґенезу з синусовим ритмом, II А-Б стадії, II-IV ФК за NYHA: 58 осіб зі зниженою ФВ, 30 - зі збереженою ФВ лівого шлуночка. Середній вік хворих -69,18 $\pm 9,97$ року, $52 \%$ чоловіків ( $\mathrm{n}=46)$. Медіана спостереження за хворими на ХСН становила 396 днів, максимальна кількість днів спостереження - 1302. За період спостереження зареєстрували 14 кінцевих точок, що становило 15,91 \% подій: 7 (8%) смертей, 2 (2,3 \%) інсульти, 2 (2,3%) випадки гострого коронарного синдрому, 3 (3,4%) випадки прогредієнтної серцевої недостатності. Виживаність оцінювали шляхом побудови кривих Каплана-Маєра, вірогідність різниці між групами розрахували за критеріями Ґегана-Вілкоксона, Кокса-Мантела та log-rank test. Визначили фактори ризику та побудували уні- та мультиваріантні моделі прогнозу регресійним аналізом пропорційних ризиків Кокса. ROC-аналізом встановлено граничні значення кількісних факторів ризику.

UDC $616.12-008.46-085.22$

DOI: $10.14739 / 2409-2932.2021 .2 .232175$

Current issues in pharmacy and medicine: science and practice 2021; 14 (2), 226-231

Key words: chronic heart failure, ACE inhibitors, MRAs, diuretics, statins, treatment.

*E-mail: Vladm.d22@gmail.com

Received: 31.03.2021 // Revised: 19.04.2021 // Accepted: 30.04.2021 
Результати. Збільшення відносного ризику несприятливих кардіоваскулярних подій у хворих на ХСН незалежно від ФВ лівого шлуночка асоціювалося з добовою дозою карведілолу понад 25 мг (BP = 1,05; $95 \%$ ДІ 1,009-1,093; $p=0,0171)$; еплеренону понад 12,5 мг (ВР = 1,073; $95 \%$ ДІ 1,005-1,144; $p=0,034)$, торасеміду понад 5 мг (ВР = 1,13; $95 \%$ ДІ 1,021-1,255; $p=0,019)$; розувастатину понад 10 мг (ВР = 1,107; $95 \%$ ДІ 1,007-1,203; $p=0,035)$, тенденцією в разі застосування аторвастатину в дозі менше ніж 10 мг (BР = 1,05; 95 \% ДІ 0,951-1,165; $p=0,327)$. Застосування раміприлу в добовій дозі менше ніж 2,5 мг супроводжувалось тенденцією до зменшення на $22 \%$ відносного ризику несприятливих кардіоваскулярних подій (BP = 0,78; $95 \%$ Дl 0,384-1,580; $p=0,491)$.

Висновки. Позитивні результати лікування хворих на ХCH незалежно від фенотипу асоціювалися з низькими добовими дозами раміприлу (<2,5 мг), еплеренону/спіронолактону (<12,5 мг), торасеміду (<5 мг), розувастатину (<10 мг), але з високими дозами аторвастатину (>10 мг).

Ключові слова: хронічна серцева недостатність, інгібітори АПФ, антагоністи мінералокортикоїдних рецепторов (АМР), діуретики, статини, лікування.

Актуальні питання фрармацевтичної і медичної науки та практики. 2021. Т. 14, № 2(36). С. 226-231

Существуют ли преимущества низких доз иАПФ, АМР, диуретиков и статинов при лечении хронической сердечной недостаточности?

\section{В. А. Лысенко}

Лечение хронической сердечной недостаточности $(\mathrm{XCH})$ очень противоречиво. Вопрос об оптимальных дозах бета-адреноблокаторов, ингибиторов АПФ, антагонистов рецепторов альдостерона, статинов у пациентов с ХСН окончательно не решен. Достижение максимально переносимых доз лекарств хотя и связано со снижением смертности, но сопровождается увеличением побочных эфрфектов препаратов.

Цель работы - представить и обсудить собственные клинические и научные данные, касающиеся роли бета-адреноблокаторов, ингибиторов ренин-ангиотензиновой альдостероновой системы, диуретиков, статинов в лечении больных ХСН, а также оптимизации режимов дозирования.

Материалы и методы. В исследование включили 88 больных XCH ишемического генеза с синусовым ритмом, II А-Б стадии, II-IV ФК по NYHA: 58 человек со сниженной ФВ, 30 - с сохраненной ФВ левого желудочка. Средний возраст больных $69,18 \pm 9,97$ года, 52 \% мужчин ( $n=46)$. Медиана наблюдения за больными с XCH составила 396 дней, максимальное количество дней наблюдения - 1302. За период наблюдения зарегистрировали 14 конечных точек, что составило 15,91 \% событий: 7 (8 \%) смертей, 2 (2,3 \%) инсульта, 2 (2,3 \%) случая острого коронарного синдрома, 3 (3,4 \%) случая прогредиентной сердечной недостаточности.

Выживаемость оценивали путем построения кривых Каплана-Майера, а вероятность разницы между группами рассчитана по критериям Гехана-Вилкоксона, Кокса-Мантела и log-rank test. Определены фракторы риска и построены уни- и мультивариантные модели прогноза регрессионным анализом пропорциональных рисков Кокса. ROC-анализом установлены предельные значения количественных фракторов риска.

Результаты. Увеличение относительного риска неблагоприятных кардиоваскулярных событий у больных ХСH независимо от ФВ левого желудочка ассоциировалось с суточной дозой карведилола более 25 мг (ОР = 1,05; 95 \% ДИ 1,009-1,093; $\mathrm{p}=0,0171)$; эплеренона более 12,5 мг (ОР = 1,073; $95 \%$ ДИ 1,005-1,144; $\mathrm{p}=0,034)$, торасемида более 5 мг (OP = 1,13; $95 \%$ ДИ 1,021-1,255; $p=0$ 0,019) розувастатина более 10 мг (ОР = 1,107; $95 \%$ ДИ 1,007-1,203; $p=0,035)$ и тенденцией при применении аторвастатина в дозе менее 10 мг (ОР = 1,05; $95 \%$ ДИ 0,951-1,165; p = 0,327). Применение рамиприла в дозе менее 2,5 мг сопровождалось тенденцией к уменьшению на 22 \% относительного риска неблагоприятных кардиоваскулярных событий (OP $=0,78 ; 95 \%$ ДИ 0,384-1,580; $p=0,491)$.

Выводы. Положительные результаты лечения больных с ХCH независимо от фенотипа ассоциировались с низкими суточными дозами рамиприла (<2,5 мг), эплеренона/спиронолактона (<12,5 мг), торасемида ( $<5$ мг), розувастатина (<10 мг), но высокими дозами аторвастатина (>10 мг).

Ключевые слова: хроническая сердечная недостаточность, ингибиторы АПФ, антагонисты минералокортикоидных рецепторов (AMP), диуретики, статины, лечение.

Актуальные вопросы фрармацевтической и медицинской науки и практики. 2021. Т. 14, № 2(36). С. 226-231

Chronic heart failure (CHF), a major cardiovascular disorder, remains a grievous clinical condition regardless of advances in medical care [1].

$\mathrm{CHF}$ is associated with impaired functional capacity, as well as significant morbidity due to frequent hospitalizations. Unfortunately, despite its poor prognosis, the management of CHF is very controversial and no therapy has been so far shown to reduce mortality, especially in heart failure with preserved ejection fraction (HFpEF) [2]. The aim of personalized medicine is to offer a tailored approach to each patient in order to provide the most effective therapy, while reducing risks and adverse effects, and avoiding unnecessary treatments [3].

The issue of optimal doses of beta-blockers, ACE inhibitors, aldosterone receptor antagonists, statins in CHF patients has not been finally resolved. Achieving the maximum tolerated doses of drugs, though related to reduced mortality, but is accompanied by an increase in adverse drug reactions. 


\section{Aim}

To present and discuss our own clinical and scientific data concerning the role of beta-blockers and inhibitors of the renin-angiotensin aldosterone system, diuretics, statins in the treatment of patients with HFrEF and HFpEF and optimization of dosage schemes.

\section{Materials and methods}

The study was conducted on the clinical base of the Department of Propaedeutics of Internal Medicine, Radiation Diagnostics and Radiation Therapy (Zaporizhzhia State Medical University) in the Cardiology Department of City Hospital No. 6 (Zaporizhzhia), in accordance with the Good Clinical Practice guidelines and the principles of the Helsinki Declaration. The study protocol was approved by the Ethics Committee of Zaporizhzhia State Medical University.

After obtaining written informed consents, the study included 88 patients with CHF of ischemic origin, stage II AB, New York Heart Association (NYHA) II-IV functional class (FC), 58 - with HFrEF and 30 - with HFpEF. The mean age of patients was $69.18 \pm 9.97$ years, men $52 \%$ $(\mathrm{n}=46)$. Groups of patients with different left ventricular ejection fraction (LVEF) were matched in age $(\mathrm{P}=0.021)$, height $(P=0.222)$, weight $(P=0.835)$, body surface area $(\mathrm{P}=0.587)$. CHF of ischemic origin was diagnosed in accordance with the Recommendations for the diagnosis and treatment of CHF (2017) of the Association of Cardiologists of Ukraine and the Ukrainian Association of Heart Failure [4].

The CHF patients with HFrEF and HFpEF did not differ in the frequency of prescribing basic drugs for the treatment of heart failure (Table 1).

Mean therapeutic doses of drugs used to treat the CHF patients are given in Table 2.

Groups of the CHF patients with different LV EF did not differ in the mean daily doses of beta-blockers, ACE inhibitors, ARBs, antiplatelet agents, statins (Table 3).

Groups of patients with CHF and different EF differed significantly in daily doses of torasemide $(\mathrm{P}=0.014)$ and spironolactone $(\mathrm{P}=0.028)$.

Cumulative endpoints were considered death, myocardial infarction, stroke, progressive heart failure, and progressive angina.

During the follow-up period (median 396 days [53-1302]), 14 endpoints were registered, which accounted for $15.91 \%$ of events: deaths 7 cases ( $8 \%$ ), strokes 2 cases ( $2.3 \%$ ), myocardial infarction 1 case $(1.15 \%)$, progressive angina 1 case $(1.15 \%)$, progressive heart failure 3 cases $(3.4 \%)$. Endpoint frequency analysis depending on the CHF phenotype did not reveal a significant difference between the study groups, $18.97 \%(11 / 58)$ vs. $10 \%(3 / 30)$; log-rank test $(\mathrm{P}=0.378)$.

Since there were no statistical differences in the number of cumulative endpoints between the groups of CHF patients with reduced and preserved LV EF, in order to determine the effects of therapy on adverse events in this cohort of patients, a single database was created combining all the CHF patients regardless of LV EF $(n=88)$.
Table 1. Frequency of prescribing basic and additional drugs to the CHF patients

\begin{tabular}{|c|c|c|c|}
\hline Group of drugs & HFrEF, n = 58 & HFpEF, $n=30$ & $\mathbf{P}$ \\
\hline beta-blockers & $98 \%(n=57)$ & $97 \%(n=29)$ & 0.7694 \\
\hline ACEi/ARB & $93 \%(n=54)$ & $97 \%(n=29)$ & 0.4427 \\
\hline - ramipril & $39 \%(n=54)$ & $23 \%(n=54)$ & 0.1355 \\
\hline MRAs & $100 \%$ & $100 \%$ & 1.0000 \\
\hline - eplerenone & $67 \%(n=39)$ & $53 \%(n=16)$ & 0.2026 \\
\hline - spironolactone & $33 \%(n=19)$ & $47 \%(n=14)$ & 0.2026 \\
\hline Loop diuretics & $95 \%(n=55)$ & $77 \%(n=23)$ & 0.0127 \\
\hline - torasemide & $84 \%(n=49)$ & $77 \%(n=23)$ & 0.4239 \\
\hline - furosemide & $11 \%(n=6)$ & $0 \%(n=0)$ & 0.0766 \\
\hline Thiazide-like diuretics & $15 \%(n=9)$ & $23 \%(n=7)$ & 0.3542 \\
\hline Statins & $97 \%(n=56)$ & $97 \%(n=29)$ & 1.0000 \\
\hline - atorvastatin & $62 \%(n=36)$ & $67 \%(n=20)$ & 0.6450 \\
\hline - rosuvastatin & $34 \%(n=20)$ & $30 \%(n=9)$ & 0.7054 \\
\hline Antiplatelet agents & $100 \%$ & $100 \%$ & 1.0000 \\
\hline - aspirin & $47 \%(n=27)$ & $40 \%(n=12)$ & 0.5923 \\
\hline - clopidogrel & $53 \%(n=31)$ & $60 \%(n=18)$ & 0.5329 \\
\hline
\end{tabular}

Table 2. The mean therapeutic doses of drugs used to treat the $\mathrm{CHF}$ patients $(n=88)$

\begin{tabular}{|l|l|l|}
\hline \multirow{4}{*}{ Class of drugs } & Name of drugs & Mean dose, M \pm SD \\
\hline \multirow{4}{*}{ ACEi } & Bisoprolol & $4.18 \pm 1.71$ \\
\cline { 2 - 3 } & Carvedilol & $15.17 \pm 11.09$ \\
\hline \multirow{3}{*}{ ARB } & Ramipril & $2.70 \pm 1.99$ \\
\cline { 2 - 3 } & Enalapril & $8.125 \pm 6.22$ \\
\cline { 2 - 3 } & Perindopril & $5.09 \pm 2.42$ \\
\hline \multirow{2}{*}{ Loop diuretics } & Valsartan & $184.00 \pm 75.89$ \\
\hline \multirow{3}{*}{ MRA } & Candesartan & $12.00 \pm 4.61$ \\
\hline \multirow{2}{*}{ Antiplatelet agents } & Torasemide & $8.40 \pm 4.50$ \\
\hline \multirow{2}{*}{ Statins } & Eplerenone & $24.77 \pm 9.46$ \\
\cline { 2 - 3 } & Spironolactone & $21.02 \pm 8.24$ \\
\hline & Clopidogrel & $75.02 \pm 0.14$ \\
\hline & Aspirin & $78.21 \pm 8.46$ \\
\hline & Atorvastatin & $20.89 \pm 5.80$ \\
\cline { 2 - 3 } & Rosuvastatin & $14.23 \pm 8.57$ \\
\hline
\end{tabular}

Statistical processing of the material was performed using the software package Statistica 13.0 (StatSoft, USA), license number JPZ8041382130ARCN10-J. The Shapiro-Wilk test was used to test the normality of the quantitative data. The parameters with normal distribution were presented as the arithmetic mean and standard deviation $(\mathrm{M} \pm \mathrm{SD})$. The results without normal distribution were demonstrated by descriptive statistics as median, lower and upper quartiles - 
Table 3. Mean daily doses of drugs used in the treatment of $\mathrm{CHF}$ patients with reduced and preserved LV EF

\begin{tabular}{|l|l|l|l|} 
Drug & $\begin{array}{l}\text { Mean daily } \\
\text { doses of drugs } \\
\text { in patients } \\
\text { with HFrEF, } \\
\text { M } \pm \text { SD }\end{array}$ & $\begin{array}{l}\text { Mean daily } \\
\text { doses of drugs } \\
\text { in patients } \\
\text { with HFpEF, } \\
\text { M } \pm \text { SD }\end{array}$ & P \\
\hline Eplerenone & $25.64 \pm 9.48$ & $22.65 \pm 9.37$ & 0.292 \\
\hline Spironolactone & $23.68 \pm 8.22$ & $17.41 \pm 7.01$ & 0.028 \\
\hline Carvedilol & $16.41 \pm 12.26$ & $11.46 \pm 5.22$ & 0.183 \\
\hline Bisoprolol & $4.53 \pm 1.88$ & $3.75 \pm 1.44$ & 0.228 \\
\hline Ramipril & $2.72 \pm 2.12$ & $2.68 \pm 1.68$ & 0.965 \\
\hline Enalapril & $8.67 \pm 7.08$ & $6.67 \pm 2.89$ & 0.661 \\
\hline Perindopril & $6.67 \pm 2.31$ & $4.50 \pm 2.33$ & 0.202 \\
\hline Valsartan & $200.00 \pm 80.00$ & $173.33 \pm 78.66$ & 0.615 \\
\hline Candesartan & $10.66 \pm 4.61$ & $16.00 \pm 0.00$ & 0.422 \\
\hline Atorvastatin & $21.67 \pm 6.96$ & $19.50 \pm 2.24$ & 0.183 \\
\hline Rosuvastatin & $15.88 \pm 9.88$ & $11.11 \pm 4.17$ & 0.181 \\
\hline Clopidogrel & $75.00 \pm 0.00$ & $75.00 \pm 0.00$ & 1.00 \\
\hline Aspirin & $76.85 \pm 6.67$ & $81.25 \pm 11.31$ & 0.136 \\
\hline Torasemide & $9.29 \pm 5.00$ & $6.52 \pm 2.35$ & 0.014 \\
\hline
\end{tabular}

$\operatorname{Me}\left(\mathrm{Q}_{25} ; \mathrm{Q}_{75}\right)$. The quantitative variables normally and non-normally distributed in the groups were compared by T-test or Mann-Whitney test, respectively, after ascertaining the normality of distribution. Using Cox proportional hazards regression analysis, univariate and multivariate prognostic models were constructed. The ROC analysis was performed to find out the cut-off values of the parameters. The survival function was estimated via the Kaplan-Meier multiple estimation method. Gehan's Wilcoxon Test, Cox-Mantel Test, Log-rank-test were used to compare cumulative endpoints in the groups. The difference was considered statistically significant at a P-value $<0.05$. All the tests were two-tailed.

\section{Results}

The study analyzed the effect of main drug classes and their daily doses on the cumulative endpoints.

The choice of beta-blocker (bisoprolol or carvedilol) did not affect long-term treatment outcomes (Log-Rank Test, $\mathrm{P}=0.234$ ). In addition, no dependence was found in using different doses of bisoprolol. At the same time, carvedilol in a daily dose of more than $25 \mathrm{mg}$ was associated with an increased relative risk of adverse cardiovascular events $(\mathrm{HR}=1.05 ; 95 \% \mathrm{CI} 1.009-1.093 ; \mathrm{P}=0.0171)$ in the CHF patients, regardless of LV EF.

The relative risk of adverse cardiovascular events demonstrated a decreasing trend by $22 \%(\mathrm{HR}=0.78 ; 95 \% \mathrm{CI}$ $0.384-1.580 ; \mathrm{P}=0.491$ ) associated with low daily doses of ramipril (less than $2.5 \mathrm{mg}$ ).

A comparison of mineralocorticoid receptor antagonists (MRAs) effect on the cumulative endpoints showed no statistically significant difference between use of spironolactone and eplerenone (Log-Rank Test WW $=0.03843$; Sum $=12.726 ;$ Var $=3.0170$; Test statistic $=0.0221269$; $\mathrm{P}=0.98235$ ). However, the eplerenone administration in doses of more than $12.5 \mathrm{mg}$ unlike spironolactone in doses of more than $12.5 \mathrm{mg}(\mathrm{P}=0.800)$ was associated with increased risk of possible adverse cardio-vascular events $(\mathrm{HR}=1.073$; $95 \%$ CI 1.005-1.144; $\mathrm{P}=0.034)$.

Similar data were obtained analyzing the effect of loop diuretic torasemide on the cumulative endpoints. Torasemide in a daily dose of more than $5 \mathrm{mg}$ significantly increased the relative risk of adverse events $(\mathrm{HR}=1.13 ; 95 \% \mathrm{CI}$ 1.021-1.255; $\mathrm{P}=0.019$ ).

As for the other classes of drugs effect on the cumulative endpoints in the CHF patients, the dependence of the results on the daily dose of statins is noteworthy. The use of rosuvastatin in a daily dose of more than $10 \mathrm{mg}$ was associated with an increase in the relative risk of cardiovascular events by $10 \%(\mathrm{HR}=1.101 ; 95 \%$ CI 1.007-1.203; $\mathrm{P}=0.034)$. Despite the lack of a significant difference between the effect of rosuvastatin and atorvastatin on the cumulative endpoints in the CHF patients (Log-Rank Test WW $=$-0.3304; Sum = 12.627; Var $=2.7681$; Test statistic $=-0.198585 ; \mathrm{P}=0.84259)$, such an association was not confirmed when using atorvastatin (Log-Rank Test, $\mathrm{p}=0.435$ ). In addition, the ROC analysis showed a reverse trend towards increased relative risk of adverse cardiovascular events in the CHF patients taking atorvastatin in doses less than $10 \mathrm{mg}$ per day.

\section{Discussion}

Beta-blockers and drugs that affect the renin-angiotensin-aldosterone system (ACE inhibitors / ARBs) have proven to be highly effective in the treatment of patients with CHF in numerous randomized controlled trials, and their combination remains a cornerstone of basic therapy. We did not find any difference in the effect of bisoprolol and carvedilol on the endpoints among the CHF patients in our study. However, it should be noted that an increase in the number of adverse events with increasing dose of carvedilol was observed. In our opinion, this association of an increased risk of adverse cardiovascular events with daily doses of carvedilol over $25 \mathrm{mg}$ was due to the need to prescribe higher doses for the CHF patients with more severe disease.

An interesting result of our study was a $22 \%$ reduction in the relative risk of adverse cardiovascular events in the $\mathrm{CHF}$ patients associated with low daily doses of ramipril (less than $2.5 \mathrm{mg}$ ). In real clinical practice, $80 \%$ of CHF patients receive doses of ACE inhibitors lower than the recommended.

Studies [5] have proven an absence of significant difference between the effects of low and high doses of ACE inhibitors on mortality $(\mathrm{HR}=0.95 ; 95 \%$ CI $0.87-1.02 ; \mathrm{P}=0.15)$, rehospitalization for decompensated $\mathrm{HF}(\mathrm{HR}=0.94 ; 95 \%$ CI $0.70-1.26 ; \mathrm{P}=0.68)$, as well as 2 times less incidence of hyperkalemia at low doses (Odds ratio $=2.07 ; 95 \% \mathrm{CI}$, $1.20-3.59 ; \mathrm{P}=0.01)$. 
In respect of diuretics, loop diuretics were prescribed significantly less often (77 \% vs. $95 \%$; $=0.0127)$ in the patients with HFpEF in our study, which is fully compatible with international and Ukrainian recommendations for the treatment of CHF patients. Groups of CHF patients with different EF also differed significantly in daily doses of torasemide $(\mathrm{P}=0.014)$ and spironolactone $(\mathrm{P}=0.028)$. It is obvious that patients with HFrEF required higher doses of these diuretics due to more pronounced fluid retention in the body.

The study on different doses of torasemide effect on cumulative endpoints allowed us to find that higher doses of the drug were associated with an increased relative risk of adverse cardiovascular events in the CHF patients. It is worth mentioning that this effect was not associated with the drug, but with the need to prescribe higher doses of torasemide in the CHF patients with a more severe course, i.e. with severe fluid retention.

Concerning spironolactone, our study showed the upward trend of risks similar to torasemide, but it did not reach the level of statistical significance $(\mathrm{HR}=1.02 ; 95 \% \mathrm{CI}$ $0.894-1.157 ; \mathrm{P}=0.800)$. The increased risk of adverse events was observed at doses of spironolactone more than $12.5 \mathrm{mg}$ (the area under the ROC curve 0.556; $\mathrm{P}=0.725$ ), but not significant.

No statistically significant difference between the groups of patients who used spironolactone or eplerenone (Log-Rank Test, $\mathrm{WW}=0.03843$, Sum $=12.726$, Var $=3.0170$, Test statistic $=0.0221269, \mathrm{P}=0.98235)$ was revealed by comparing the effect of mineralocorticoid receptor antagonists on cumulative endpoints. However, only the eplerenone use at doses more than $12.5 \mathrm{mg}$ per day in contrast to spironolactone at the same doses, was associated with the significantly increased risk of adverse cardiovascular events by $7 \%$ $(\mathrm{P}=0.034)$.

The positive effect of MRAs in cardiac pathology has been proven in studies RALES [6], TOPCAT [7]. It has been shown that even low doses of MRAs provide a protective effect. The use of high doses of MRAs increased the risk of hyperkalemia. In the EMPHASIS HF study, the incidence of hyperkalemia $(\mathrm{K}+>5.5 \mathrm{mmol} / \mathrm{L})$ was $11.8 \%$ in the eplerenone group and $7.2 \%$ in the placebo group $(\mathrm{P}<0.001)$. Importantly, a significant difference in the incidence of hyperkalemia in patients receiving eplerenone or placebo did not lead to an increase in mortality. A post hoc analysis of the EPHESUS study also showed that in patients with congestive heart failure, a $4.4 \%$ increase in the incidence of hyperkalemia in the eplerenone group was not accompanied by an increase in a mortality or hospitalization rate [8]. Similar results were obtained in the RALES study with spironolactone treatment [6].

A multicenter, prospective, randomized, double-blind, placebo-controlled study of Aldo-DHF examined the effect of spironolactone at a daily dose of $25 \mathrm{mg}$ compared with placebo on the diastolic function and physical well-being of 422 patients with HFpEF. The observation period for patients was 12 months. Spironolactone improved diastolic function and caused reverse LV remodeling, but did not affect maximal exercise, patient symptoms, or the quality of life [9].

In a randomized double-blind trial TOPCAT, which included 3445 individuals, patients with symptomatic heart failure and $\mathrm{EF} \geq 45 \%$ were randomized to receive spironolactone 15-45 mg per day or placebo. The mean follow-up was 3.3 years. In this study, spironolactone did not significantly reduce morbidity, the primary cumulative point - death from cardiovascular causes, cardiac arrest or hospitalization rate due to progression of heart failure [7].

In a large meta-analysis of 16.321 patients from 15 randomized controlled trials, MRA therapy reduced the risk of cardiovascular death, all-cause mortality, and cardiac hospitalization rate in patients with HFrEF, but these benefits were not demonstrated in patients with HFpEF [2].

In a meta-analysis of 14 randomized controlled clinical trials involving 6428 patients with HFpEF or myocardial infarction with preserved EF, MRA therapy reduced the number of hospitalizations for CHF by $17 \%$, improved diastolic function, and resulted in improved remodeling and life. However, MRA therapy had not been able to reduce all-cause mortality [10].

Statins are usually prescribed to patients with CHF of ischemic origin to prevent cardiovascular complications. Analysis of the statin effect on the endpoints in our study suggests that these drugs have dose-dependent properties. So, the clinical efficacy of atorvastatin in the CHF patients increased with increasing dose, while the best long-term results were observed when using rosuvastatin in a daily dose of less than $10 \mathrm{mg}$. Similar results were obtained in the study PROVE-IT TIMI [11]: high doses of atorvastatin to a greater extent than high doses of pravastatin reduced the risk of developing $\mathrm{CHF}$ in patients with acute coronary syndrome $(\mathrm{HR}=0.55 ; 95 \% \mathrm{CI}, 0.35-0.85, \mathrm{P}=0.008)$. However, these data relate to the primary prevention of CHF in patients with acute coronary syndrome.

The influence of molecular differences of statins on their pharmacological and pleiotropic effects is probably important. The cardiac effects of atorvastatin may be related to its lipophilic properties and ability to penetrate cardiomyocytes as opposed to hydrophilic rosuvastatin. However, in the PEARL study [12] with lipophilic pitavastatin in CHF patients, there were no differences in the frequency of the primary endpoint (hospitalization due to worsening of heart failure and cardiac death) compared with a placebo group. In this study, a subgroup of patients with $E F \geq 30$ showed a slightly lower incidence of primary endpoint on pitavastatin treatment compared with placebo, whereas patients with EF $<30 \%$ taking this drug, in contrast, demonstrated a tendency to reach it more frequently.

The non-lipid effects of rosuvastatin have the potential to promote endogenous tissue regeneration and improve LV EF in CHF. Rosuvastatin has been shown to activate circulating progenitor cells in CHF, which promotes neovascularization and enhances endothelial function. Correction of vascular abnormalities partially led to an increase in LV function by $+27 \%(\mathrm{P}<0.001$, compared with placebo $)[13]$. 
Despite the positive preconditions for the rosuvastatin action in heart failure patients in the UNIVERSE study, negative results were obtained with the use of rosuvastatin in CHF. The authors believe that the expected beneficial effect of 26 weeks of statin therapy on cardiac remodeling may have been offset by an increase in collagen metabolism markers (Serum types I and III N-terminal procollagen peptide (PINP and PIIINP), and a decrease in plasma CoQ10 levels in CHF patients [14]. However, treatment with any statin, not just rosuvastatin, reduces circulating CoQ10. This effect of statins is not associated with drug solubility, intensity or duration of treatment [15].

\section{Conclusions}

Positive treatment outcomes (according to the Cox proportional-hazards regression analysis) in the CHF patients, regardless of the phenotype, were associated with low daily doses of ramipril $(<2.5 \mathrm{mg})$, eplerenone/spironolactone $(<12.5 \mathrm{mg})$, torasemide $(<5 \mathrm{mg})$, rosuvastatin $(<10 \mathrm{mg})$, but with high doses of atorvastatin $(>10 \mathrm{mg})$.

Conflicts of interest: author has no conflict of interest to declare. Конфлікт інтересів: відсутній.

\section{Information about author:}

Lysenko V. A., MD, PhD student of the Department of Propaedeutics of Internal Medicine, Radiation Diagnostics and Therapy, Zaporizhzhia State Medical University, Ukraine.

ORCID ID: 0000-0001-7502-0127

\section{Відомості про автора:}

Лисенко B. A., PhD-аспірант каф. пропедевтики внутрішньої медицини, променевої діагностики та променевої терапії, Запорізький державний медичний університет, Україна.

\section{Сведения об авторе:}

Лысенко B. A., PhD-аспирант каф. пропедевтики внутренней медицины, лучевой диагностики и лучевой терапии, Запорожский государственный медицинский университет, Украина.

\section{References}

[1] Abebe, T. B., Gebreyohannes, E. A., Tefera, Y. G., Bhagavathula, A. S., Erku, D. A., Belachew, S. A., Gebresillassie, B. M., \& Abegaz, T. M. (2018). The prognosis of heart failure patients: Does sodium level play a significant role?. PloS one, 13(11), e0207242. https://doi. org/10.1371/journal.pone.0207242

[2] Kosmas, C. E., Silverio, D., Sourlas, A., Montan, P. D., \& Guzman, E. (2018). Role of spironolactone in the treatment of heart failure with preserved ejection fraction. Annals of translational medicine, 6(23), 461. https://doi.org/10.21037/atm.2018.11.16

[3] Ferreira, J. P., Mentz, R. J., Pizard, A., Pitt, B., \& Zannad, F. (2017). Tailoring mineralocorticoid receptor antagonist therapy in heart failure patients: are we moving towards a personalized approach?. European journal of heart failure, 19(8), 974-986. https://doi.org/10.1002/ejhf.814

[4] Voronkov, L. H., Amosova, K. M., Dziak, H. V., Zharinov, O. Y., Kovalenko, V. M., Korkushko, O. V., Nesukai, O. H., Parkhomenko, O. M., Rudyk, Yu. S., \& Sychov, O. S. (2017). Rekomendatsii Asotsiatsii kardiolohiv Ukrainy z diahnostyky ta likuvannia khronichnoi sertsevoi nedostatnosti (2017) [Recommendation of Association of Cardiologists of Ukraine for the treatment of chronic heart failure in adults (2017)]. Kyiv. [in Ukranian].

[5] Khan, M. S., Fonarow, G. C., Ahmed, A., Greene, S. J., Vaduganathan, M., Khan, H., Marti, C., Gheorghiade, M., \& Butler, J. (2017). Dose of Angiotensin-Converting Enzyme Inhibitors and Angiotensin
Receptor Blockers and Outcomes in Heart Failure: A Meta-Analysis Circulation. Heart failure, 10(8), e003956. https://doi.org/10.1161/ CIRCHEARTFAILURE.117.003956

[6] Ferreira, J. P., Rossello, X., Eschalier, R., McMurray, J., Pocock, S. Girerd, N., Rossignol, P., Pitt, B., \& Zannad, F. (2019). MRAs in Elderly HF Patients: Individual Patient-Data Meta-Analysis of RALES, EMPHASIS-HF, and TOPCAT. JACC. Heart failure, 7(12), 1012-1021. https://doi.org/10.1016/j.jchf.2019.08.017

[7] Fudim, M., Kelly, J. P., Brophy, T. J., DeVore, A. D., Hammill, B. G., Peterson, E. D., Pitt, B., Yancy, C., Fonarow, G. C., \& Hernandez, A. F. (2020). Trends in Treatment for Patients Hospitalized with Heart Failure with Preserved Ejection Fraction Before and After Treatment of Preserved Cardiac Function Heart Failure With an Aldosterone Antagonist (TOPCAT). The American journal of cardiology, 125(11), 1655-1660. https://doi.org/10.1016/i.amjcard.2020.02

[8] Murphy, S. P., Ibrahim, N. E., \& Januzzi, J. L., Jr (2020). Heart Failure With Reduced Ejection Fraction: A Review. JAMA, 324(5), 488-504. https://doi.org/10.1001/jama.2020.10262

[9] Edelmann, F., Wachter, R., Schmidt, A. G., Kraigher-Krainer, E., Colantonio, C., Kamke, W., Duvinage, A., Stahrenberg, R., Durstewitz, K., Löffler, M., Düngen, H. D., Tschöpe, C., Herrmann-Lingen, C., Halle, M., Hasenfuss, G., Gelbrich, G., Pieske, B., \& Aldo-DHF Investigators (2013). Effect of spironolactone on diastolic function and exercise capacity in patients with heart failure with preserved ejection fraction: the Aldo-DHF randomized controlled trial. JAMA, 309(8), 781-791. https://doi.org/10.1001/jama.2013.905

[10] Chen, Y., Wang, H., Lu, Y., Huang, X., Liao, Y., \& Bin, J. (2015). Effects of mineralocorticoid receptor antagonists in patients with preserved ejection fraction: a meta-analysis of randomized clinical trials. BMC medicine, 13, 10. https://doi.org/10.1186/s12916-014-0261-8

[11] Tsuda, K., Kataoka, Y., Ogata, S., Nishimura, K., Nishikawa, R. Doi, T., Nakashima, T., Hosoda, H., Honda, S., Kawakami, S., Fujino, M., Nakao, K., Yoneda, S., Nishihira, K., Otsuka, F., Tahara, Y., Asaumi, Y., Hoshiga, M., Noguchi, T., \& Yasuda, S. (2020). Diminished response to statins predicts the occurrence of heart failure after acute myocardial infarction. Cardiovascular diagnosis and therapy, 10(4), 705-716. https://doi.org/10.21037/cdt-20-415

[12] Takano, H., Mizuma, H., Kuwabara, Y., Sato, Y., Shindo, S., Kotooka, N., Fujimatsu, D., Kobayashi, Y., Inoue, T., Node, K., Komuro, I., \& PEARL Study Investigators (2013). Effects of pitavastatin in Japanese patients with chronic heart failure: the Pitavastatin Heart Failure Study (PEARL Study). Circulation journal, 77(4), 917-925. https://doi. org/10.1253/circj.cj-12-1062

[13] Erbs, S., Beck, E. B., Linke, A., Adams, V., Gielen, S., Kränkel, N. Möbius-Winkler, S., Höllriegel, R., Thiele, H., Hambrecht, R., \& Schuler, G. (2011). High-dose rosuvastatin in chronic heart failure promotes vasculogenesis, corrects endothelial function, and improves cardiac remodeling--results from a randomized, double-blind, and placebo-controlled study. International journal of cardiology, 146(1), 56-63. https://doi.org/10.1016/j.ijcard.2010.02.019

[14] Ashton, E., Windebank, E., Skiba, M., Reid, C., Schneider, H., Rosenfeldt, F., Tonkin, A., \& Krum, H. (2011). Why did high-dose rosuvastatin not improve cardiac remodeling in chronic heart failure? Mechanistic insights from the UNIVERSE study. International journal of cardiology, 146(3), 404-407. https://doi.org/10.1016/j.ijcard.2009.12.028

[15] Qu, H., Meng, Y. Y., Chai, H., Liang, F., Zhang, J. Y., Gao, Z. Y., \& Shi, D. Z. (2018). The effect of statin treatment on circulating coenzyme Q10 concentrations: an updated meta-analysis of randomized controlled trials. European journal of medical research, 23(1), 57. https://doi.org/10.1186/s40001-018-0353-6 